Robert Radek

Uniwersytet Ślaski w Katowicach

\title{
SKUTECZNOŚĆ LEGISLACYJNA GABINETÓW MNIEJSZOŚCIOWYCH (WYBRANE ASPEKTY)
}

We współczesnych reżimach demokratycznych rząd jest tym ciałem, które zajmuje główne miejsce w systemie organów władzy publicznej, jest naczelnym organem administracji i jednocześnie zasadniczym organem władzy wykonawczej. To rząd podejmuje wysiłki zamierzające do wypracowania głównych założeń polityki oraz zapewnia ich realizację przy pomocy wszystkich posiadanych instrumentów. Rząd, na którym spoczywa główna odpowiedzialność za realizację potrzeb społecznych, nakreśla perspektywy rozwoju kraju. W związku z tym legitymacja gabinetu uzyskana od suwerena poprzez stworzenie odpowiedniej większości parlamentarnej jest kluczowa w zakresie planowania polityki państwa. To w parlamentarnej konstelacji partyjnej ukryta jest siła zaufania do działań rządu i jego pomysłów legislacyjnych mających na celu wdrażanie planowanych celów politycznych. Przedmiotem rozważań w niniejszym artykule jest przeanalizowanie wybranych aspektów w zakresie skuteczności legislacyjnej gabinetów mniejszościowych ${ }^{1}$.

Autor stawia hipotezę, że funkcjonowanie rządów bez wyraźnego większościowego zaplecza politycznego w parlamencie utrudnia lub wręcz całkowicie uniemożliwia uchwalanie ustaw o dużym wpływie społecznym. W związku z tym można zauważyć zależność skuteczności legislacji od posiadanego przez rząd zaplecza politycznego. Jeśli wzrasta siła zaplecza politycznego rządu, jego skuteczność legislacyjna rośnie, zaś w sytuacji utraty większości gabinetowej owa skuteczność również maleje. Stopień tej zależności nie jest jednakowy wszędzie i w dużym stopniu zależy od specyfiki systemu rządów.

Gabinety mniejszościowe są nietypową formą funkcjonowania egzekutywy w systemach parlamentarno-gabinetowych. Jako odstępstwo od normy nie są traktowane jako pożądana forma działania władzy wykonawczej. W konsekwencji badania nad tym zjawiskiem nie są zaawansowane i nadal pomimo pojawiania się różnych opracowań na gruncie krajowym i międzynarodowym można odnotować ich deficyt. Wśród opracowań poświęconych tej tematyce wymienić można m.in.: K. Strøm, Minority Government and Majority Rule, Cambridge 1990; P. Zakrzewski, Rząd mniejszościowy - zagadnienia definicyjne i przegląd stanowisk teoretycznych, (w:) J. Błuszkowski, J. Zaleśny (red.), Wielowymiarowość systemów politycznych. Teoretyczne założenia i praktyczne uwarunkowania, Warszawa 2009; R. Mróz, Rząd mniejszościowy, „Przegląd Sejmowy” 2013, nr 1; Rządy mniejszościowe w wybranych państwach świata. Studium prawno-politologiczne, R. Radek (red.), Katowice 2014; P. Zakrzewski, Rządy mniejszościowe w III Rzeczypospolitej, Warszawa 2015. 
System rządów wpływa również na pozycję ustrojową rządu. Jego pozycja jest inna $\mathrm{w}$ systemie parlamentarnym, jeszcze inna w prezydenckim, a jeszcze inna w mieszanym, czy komitetowym. Warto podkreślić, że w systemach parlamentarnogabinetowych rząd wyłaniany jest przez większość parlamentarną, która ma szansę się ukształtować dzięki temu, że uzyskuje poparcie wyborców dla prezentowanego programu wyborczego. W związku z tym podczas kampanii wyborczej podejmowane są wielotorowe działania, które w zamyśle strategów partyjnych mają doprowadzić do uzyskania tak dużego poparcia wyborców, aby możliwe było samodzielne formowanie rządu przez zwycięską partię polityczną. Takie warunki są najbardziej korzystne z punktu widzenia realizacji celów politycznych i głoszonego $\mathrm{w}$ trakcie kampanii programu wyborczego, gdyż samodzielne objęcie steru rządów pozwala swobodnie i bez konieczności budowania kompromisowych rozwiązań realizować te przyjęte założenia normatywno-polityczne. Przywódca polityczny stojący na czele większości parlamentarnej tworzy rząd i rozpoczyna realizację programu wyborczego poprzez stosowne tworzenie programu prac legislacyjnych. Aby ów program był efektywnie realizowany większość parlamentarna musi zapewnić warunki jego realizacji i dlatego utworzony rząd powinien kontrolować prace legislacyjne parlamentu. Taka właśnie jest logika systemu parlamentarno-gabinetowego, w którym kategoria skuteczności jest przede wszystkim oceniana przez wyborców². W klasycznych systemach parlamentarno-gabinetowych, np. w Wielkiej Brytanii, czy Kanadzie, to premier ostatecznie decyduje tak o tempie i kolejności podejmowanych inicjatyw ustawodawczych, jak i porządku prac parlamentarnych, wyznaczając cele strategiczne. Poza uwarunkowaniami typowo konstytucyjnymi w konstelacji parlament - rząd - głowa państwa istotną rolę odgrywają także czynniki behawioralne, tradycja ustrojowa, czy też stopień i trwałość ukształtowania się systemu partyjnego. Władza wykonawcza w formie rządu, będąc wyposażona w zaplecze urzędniczo -eksperckie jest predestynowana do inicjowania procesu ustawodawczego. Niemniej jednak potrzeba jest również zbudowania równowagi pomiędzy demokratycznie wybranym parlamentem a skutecznie działającą egzekutywą, tak by żadna ze stron nie zdobyła nadmiernej władzy, a z drugiej by mogła jednak efektywnie ją sprawować i realizować cele polityczne zaakceptowane przez wyborców ${ }^{3}$.

Obecnie obowiązująca Konstytucja RP z dnia 2 kwietnia 1997 roku w artykule 10 wyraża ustrojową zasadę podziału i równowagi władzy ustawodawczej (Sejm i Senat), wykonawczej (Prezydent Rzeczypospolitej Polskiej i Rada Ministrów) i sądowniczej (sądy i trybunały), choć co należy podkreślić ów podział nie ma charakteru bardzo ścisłego i dokładnego oraz nie zawsze oznacza równorzędność. Ustrojodawcy zależało bardziej na takiej interpretacji, aby nie pojawiło się w systemie uzależnienie jednej z władz od drugiej, na przykład uzależnienie legislatywy 
od monopolu w zakresie inicjatywy ustawodawczej egzekutywy. W związku z tym zasada podziału władz nie ma jedynie charakteru organizacyjnego, lecz także oznacza, że każdej z władz powinny być przyporządkowane kompetencje materialnie odpowiadającej ich istocie, oraz że każda $\mathrm{z}$ nich powinna zachować pewne minimum wyłączności kompetencyjnej stanowiącej o zachowaniu tej istoty. W literaturze przedmiotu dość powszechny jest pogląd, że podział władz ma charakter dwuwymiarowy - funkcjonalny i strukturalny ${ }^{4}$. Podział funkcjonalny oznacza, że działalność władzy państwowej sprowadza się do stanowienia i wykonywania prawa oraz do orzekania, zaś podział strukturalny sprowadza się do takiego uporządkowania organów władzy, aby mogły one pełnić różne funkcje. Natomiast równowaga podzielonych władz najczęściej jest interpretowana jako powściąganie jednej władzy przed drugą zgodnie z systemem „hamulców i równowagi”, co w szczególności obejmuje kontrolę rządu przez parlament $w$ imieniu suwerena. $Z$ drugiej strony współpraca pomiędzy władzami staje się obowiązkiem wynikającym z pragmatyki rządzenia w państwie demokratycznym ${ }^{5}$. Podzielnie władzy publicznej z jednoczesnym stworzeniem konieczności komunikacji implikuje wzajemną kontrolę i zdecydowanie utrudnia podejmowanie bardzo ekspansywnych działań godzących w podstawowe prawa obywatela w państwie ${ }^{6}$. Istotą zasady podziału władz kreującej odrębność każdej z nich jest stworzenie autonomii wewnętrznej, dotyczącej wewnętrznej organizacji w tworzeniu zaplecza eksperckiego, czy określaniu zasad funkcjonowania. Podział władzy w odniesieniu do relacji między egzekutywą a legislatywą odnosi się do koncepcji ,istoty władzy”, jako przypisania naturalnych kompetencji każdej z władz. Dlatego dopuszczalne jest uzależnienie władzy wykonawczej od ustawodawczej, przy czym granice asymetryczności tych stosunków uwarunkowane są „istotą danej władzy”"

Podczas prac nad Konstytucją RP z 1997 roku posiłkując się różnymi modelami, m.in. parlamentarno-gabinetowym, parlamentarno-prezydenckim i prezydenckim przy normowaniu pozycji ustrojowej Prezesa Rady Ministrów i relacji izby niższej z Radą Ministrów, wykorzystano niektóre wzorce systemu kanclerskiego. Wzmocnienie rządu traktowane jako wyraźna racjonalizacja jego relacji z parlamentem skutkowało wzmocnieniem pozycji premiera, choć ostatecznie nie doprowadziło do wytworzenia się systemu rządów premierowskich. Zasadniczym celem takich rozwiązań było zagwarantowanie stabilności rządów z jednoczesnym zapewnieniem sprawności działania parlamentu sprawującego przecież kontrolę polityczną nad rządem. Niebagatelny wpływ na ostateczny kształt systemu rządów miała również praktyka okresu transformacji ustrojowej, w tym zwłaszcza doświadczenia sys-

4 R. Mojak, Parlament a rząd w ustroju Trzeciej Rzeczypospolitej Polskiej, Lublin 2007, s. 104 in.

$5 \quad$ M. Mistygacz, Rząd w procesie..., op. cit., s. 38.

$6 \quad$ Na ten temat zobacz szereg opracowań Ryszarda Małajnego, m.in. R. Małajny, Idea rozdziału władzy państwowej i jej interpretacje, „Przegląd Sejmowy” 2009, nr 1, s. 81 i n.; R. Małajny, Trzy teorie podzielonej władzy, Warszawa 2001, s. 204 i n. 
temu rządów prezydencko-parlamentarnych. Eklektyczny charakter tego systemu, polegający na integrowaniu rozwiązań systemów: parlamentarno-gabinetowego, parlamentarno-prezydenckiego i kanclerskiego miał w założeniach doprowadzić do zracjonalizowania systemu i uniknięcia typowych wad czystego systemu parlamentarnego ${ }^{8}$. W parlamentarnym systemie rządów, w którym mamy do czynienia z osłabioną pozycją egzekutywy (rządu i głowy państwa) oraz słabymi partiami politycznymi, najczęstszym efektem finalnym takiej sytuacji jest ostateczne osłabienie samego parlamentu wskutek permanentnych kryzysów politycznych. Aby zneutralizować te zagrożenia, pojawiły się koncepcje racjonalizujące system parlamentarny, które miały usprawnić system rządów poprzez wprowadzenie rozwiązań funkcjonalnych dla poprawnych relacji egzekutywa-legislatywa. Przesunięto w związku z tym akcent z demokratyczności jako takiej na rzecz stabilności systemu rządów, głównie poprzez zapobieganie supremacji jakiejkolwiek z władz. Zatem jak podkreśla Jarosław Szymanek celem racjonalizacji jest $w$ istocie odbudowanie zachwianych proporcji pomiędzy poszczególnymi elementami systemu rządów, a następnie jurydyzacja reguł funkcjonowania tego systemu?.

Racjonalizacja systemu rządów parlamentarnych dokonała się zasadniczo w czterech obszarach, dotyczących: ukonstytuowania ustrojowego statusu szefa rządu, egzekwowania politycznej odpowiedzialności gabinetu, określenia stosunków panujących wewnątrz dualnej egzekutywy oraz usprawnienia procesu ustawodawczego. $Z$ uwagi na przedmiot rozważań w niniejszym opracowaniu interesujące wydają się dwie kwestie spośród wymienionych. Pierwszą stanowi aktywny udział rządu w procesie ustawodawczym, niekiedy przyjmujący postać dominacji egzekutywy nad legislatywą w zakresie wpływu na ostateczny kształt uchwalonego aktu prawnego. Natomiast drugą jest kontrola parlamentu nad działaniami legislacyjnymi rządu, realizowana za pomocą mechanizmów politycznej odpowiedzialności gabinetu przed parlamentem, a tak de facto przed istniejącą większością parlamentarną. Te podstawowe zasady ogólnych systemowych relacji pomiędzy legislatywą a egzekutywą $\mathrm{w}$ procesie legislacyjnym $\mathrm{w}$ poszczególnych ustrojach podlegają modyfikacjom zarówno z uwagi na praktykę polityczną (tak stało się w Wielkiej Brytanii), jak i na świadomy wybór określonego modelu stosunków parlamentu z rządem dokonanego przez ustrojodawcę (charakterystyczne dla V Republiki Francuskiej i Republiki Federalnej Niemiec $)^{10}$.

W kontekście polskich obecnych rozwiązań ustrojowych oraz praktyki politycznej można stwierdzić, że polska ustawa zasadnicza w jej aktualnym kształcie tylko połowicznie wpisuje się $\mathrm{w}$ formułę zracjonalizowanego systemu rządów parlamentarnych. Poza wszelką wątpliwością odnosi się to do sfery mechanizmów egzekwo-

Nie wszyscy badacze zgadzają się z tą opinią i można także spotkać się z całkowicie odmiennym stanowiskiem. J. Szymanek, Racjonalizacja parlamentarnego systemu rządów, „Przegląd Sejmowy” 2007, nr 1, s. 42.

S. Patyra, Wpływ Rady Ministrów na proces ustawodawczy w kontekście racjonalizacji systemu rządów, (w:) M. Paździor, B. Szmulik (red.), Wybrane aspekty parlamentaryzmu zracjonalizowanego, Lublin 2011, s. 119-120. 
wania odpowiedzialności politycznej przed parlamentem oraz prawnoustrojowego statusu premiera jako rzeczywistego szefa rządu wyposażonego w realne instrumenty kierowania i koordynowania podległego mu zespołu ministrów. W odniesieniu do politycznej odpowiedzialności rządu najbardziej spektakularnym przejawem racjonalizacji jest redukcja procedur prowadzących do obalenia rządu przez Sejm i przyjęcie zasady konstruktywnego wotum nieufności jako jedynej skutecznej w tym zakresie formuły. Co więcej, formuła ta prowadzi nawet do utrzymywania się gabinetu nie mającego poparcia większości w parlamencie, przez co skuteczność procesu legislacyjnego staje pod dużym znakiem zapytania. Zdecydowanie słabiej natomiast przedstawia się regulacja konstytucyjna w dwóch pozostałych obszarach racjonalizacji systemu, tzn. w sferze kształtowania wzajemnych relacji $\mathrm{w}$ ramach dualnej egzekutywy oraz w płaszczyźnie normatywnego modelu procesu ustawodawczego i roli, jaką w tym procesie odgrywa rząd ${ }^{11}$. Polski model relacji między egzekutywą a legislatywą w procesie ustawodawczym określany jako model mieszany nie jest, jak często się podkreśla, modelem spójnym ustrojowo. Jego cechą charakterystyczną jest wysoka pozycja parlamentu i w konsekwencji ustawy (rozwiązanie właściwe dla modelu amerykańskiego ${ }^{12}$ ), a także znacząca rola projektów rządowych (typowe rozwiązanie dla modelu westminsterskiego ${ }^{13}$ ). Polski model działalności rządu w sferze legislacyjnej charakterystyczny jest dla państw Europy kontynentalnej i wyróżnia się następującymi właściwościami:

- zasadnicza regulacja procesu legislacyjnego zawarta jest w Konstytucji i regulaminach izb parlamentu,

- istnienie materii właściwej tylko dla ustaw,

- prymat w stosunku do aktów wykonawczych wydawanych przez organy władzy wykonawczej,

- większość ustaw jest uchwalana z inicjatywy rządu,

- obowiązuje zasada kilku czytań projektu ustawy,

- zasadnicza część pracy nad projektami odbywa się na posiedzeniach parlamentarnych,

- istnienie dyscypliny partyjnej ${ }^{14}$.

11 Ibidem, s. 120-121, M. Mistygacz, Rola rządu w procesie ustawodawczym (w systemie parlamentarnym), (w:) T. Mołdawa, J. Szymanek, M. Mistygacz (red.), Parlamentarny system rządów. Teoria i praktyka, Warszawa 2012, S. 284.

12 W modelu amerykańskim organ egzekutywy nie dysponuje formalnymi środkami oddziaływania na proces ustawodawczy, bowiem nie ma prawa inicjatywy ustawodawczej, czy wnoszenia poprawek, a jedynym środkiem wpływu jest teoretycznie zawieszające „weto” ustawodawcze, de facto stanowiące jedyny skuteczne narzędzie kontroli ustawodawstwa.

13 W modelu westminsterskim to rząd całkowicie kieruje procesem ustawodawczym, co wynika ze specyfiki układu władzy. To kierownictwo partii zwycięskiej umożliwia uchwalenie wszystkich zaproponowanych przez rząd rozwiązań, a blokowanie tych, które są autorstwa opozycji.

14 H. Rot, Wartości demokratyczne i racjonalistyczne studium ustanawiania aktów prawotwórczych, (w:) H. Rot (red.), Demokratyczne państwo prawne (aksjologia, struktura, funkcje), Wrocław 1994, s. 128. 
Pożądane w systemie rządów parlamentarnych współdziałanie trzech najistotniejszych segmentów władzy politycznej parlamentu, rządu i prezydenta stanowi istotny element stabilizujący i wzmacniający skuteczność polityczną. Właśnie w normatywnym modelu postępowania ustawodawczego, jak w soczewce, skupia się cała demokratyczna aksjologia tego systemu, co odpowiednio dotyczy także zakresu partycypacji rządu w tym procesie. Pozycję ustrojową Rady Ministrów, jako głównego piastuna władzy wykonawczej, charakteryzują przyznane konstytucyjnie kompetencje, określone funkcje i wyznaczone na ich podstawie zadania. Rządowi została przyznana funkcja rządzenia, czyli prowadzenia wewnętrznej i zewnętrznej polityki państwa w sposób permanentny. To Rada Ministrów decyduje o stanowiskach w zasadniczych obszarach polityki krajowej i międzynarodowej ustalając ogólny, strategiczny kierunek polityki państwa, jak i plany taktyczne i operacyjne ${ }^{15}$. Stanowi to, że bezpośrednio odniesienie zarówno do zasady podziału, jak i równowagi władz, określa też funkcjonalne rozróżnienie pomiędzy rządem i prezydentem. Rada Ministrów jako organ pośrednio przedstawicielski, który najczęściej jest konstruowany w następstwie wyborów parlamentarnych w oparciu o regułę większości, prowadząc politykę państwa, urealnia decyzje suwerena, który nie tylko legitymizuje w głosowaniu określone formacje polityczne, ale także opowiada się za realizacją forsowanej przez nie wizji programowej. Rozliczenie tej wizji oraz ocena społecznych i politycznych skutków jej realizacji pozostaje w gestii Sejmu, przed którym rząd ponosi bezpośrednią odpowiedzialność polityczną, a także w gestii samych wyborców, którzy mogą rozliczyć Radę Ministrów cyklicznie podczas kolejnych elekcji ${ }^{16}$.

Udział rządu w postępowaniu ustawodawczym ma nie tylko wymiar praktyczny, przekładający się na ocenę skuteczności rządzenia, ale również jest doniosły z punktu widzenia zasady legalizmu oraz innych komponentów demokratycznego państwa prawnego. W państwie, które chce być traktowane nie tylko poważnie, ale również postrzegane jako hołdujące zasadzie państwa prawnego, program polityczny może być jedynie realizowany poprzez ustawy, zwłaszcza tam gdzie nie istnieje rządowe ustawodawstwo delegowane. Zgodnie bowiem z imperatywem współdziałania legislatywy i egzekutywy w tym systemie, ustawa powinna być zatem wspólnym dziełem rządu i parlamentu, w ten oto sposób, że rząd przygotowuje projekty, natomiast parlament je uchwala, tym samym umożliwiając realizację kluczowej dla rządu funkcji rządzenia. Oprócz tego dodatkowym czynnikiem podnoszącym rangę roli legislacyjnej rządu jest aspekt prawodawczy na szczeblu Unii Europejskiej, co znajduje wyraz w konstrukcji unijnego procesu decyzyjnego. Najbardziej charakterystyczną cechą unijnego procesu legislacyjnego jest konwersja ustrojowych ról legislatywy i egzekutywy względem klasycznego podziału władzy.

Zob. art. 146 ust. 1 i 2 Konstytucji Rzeczypospolitej Polskiej z dnia 2 kwietnia 1997 r. (Dz.U. z 1997 r. Nr 78 , poz. 483 ze zm.). O zadaniach, kompetencja i funkcjach Rady Ministrów szerzej w m.in.: M. Mistygacz, Rząd w procesie..., op. cit., s. 52 i n.
} 
To egzekutywa właściwie tworzy prawo unijne z udziałem parlamentu, zaś parlamenty państw członkowskich ewentualnie je wykonują, gdy przybiera ona postać dyrektyw i kontrolując przedstawicieli rządu w unijnych strukturach decyzyjnych, jednocześnie kontrolują ów proces legislacyjny w interesie narodowego suwerena ${ }^{17}$.

Aktualnie obowiązujące polskie rozwiązania konstytucyjne dedykują Radzie Ministrów tylko kilka instrumentów normatywnych, dzięki którym jest ona w stanie wpływać na proces ustawodawczy. Do instrumentów tych należy w pierwszym rzędzie prawo inicjatywy ustawodawczej ${ }^{18}$, które powszechnie uznawane jest za nieredukowalną zasadę w systemie parlamentarno-gabinetowym, a dotychczasowe doświadczenia polskiego konstytucjonalizmu wskazują, że rząd zawsze był podmiotem wyposażonym w to prawo.

W Polsce inicjatywy ustawodawcze rządu są, co do zasady, równouprawnione z inicjatywami pozostałych podmiotów, choć pojawiały się w okresie uchwalania obecnie obowiązującej konstytucji propozycje nadania priorytetu projektom rządowym $^{19}$. Dotychczasowe doświadczenia pokazują, że Rada Ministrów jest najaktywniejszym podmiotem z grona pięciu wyposażonych przez Konstytucję w to prawo. Wszystkie projekty ustaw wnoszone przez rząd obwarowane są szczególnymi wymogami formalnymi, wśród których wymienić można m.in.: obowiązek konsultacji, obowiązek sporządzenia skutków społeczno-ekonomicznych związanych z wejściem w życie aktu, sporządzenie projektu aktów wykonawczych ${ }^{20}$. Projekty ustaw wnoszone przez pozostałe uprawnione podmioty, a dotyczące tego samego przedmiotu projektowanej regulacji traktowane są identycznie jak propozycje rządowe.

W przypadku rządu niezwykle istotna jest aktywność drugiego członu władzy wykonawczej, a mianowicie prezydenta. Uprawnienie osobiste głowy państwa w zakresie inicjatywy ustawodawczej może bowiem sprzyjać destabilizacji i rywalizacji w łonie dualnej egzekutywy, co niestety przekładać się może na jakość rządzenia. Abstrahując od intencji tak rządu, jak i samego prezydenta, może się okazać, że obie strony będą wzajemnie ze sobą konkurowały, a nawet celowo przeszkadzały w realizacji postawionych celów politycznych. Nabierać to może szczególnego znaczenia w dwóch sytuacjach. Pierwszą z nich jest sytuacja koabitacji, a drugą pojawienie się gabinetu mniejszościowego. W obu przypadkach, a zwłaszcza w drugim z wymienionych, rola prezydenta w systemie politycznym i jego oddziaływanie na proces legislacyjny może znacząco wzrosnąć. Po części wynikać to może z faktu, iż część elit politycznych w zdestabilizowanym parlamencie ${ }^{21}$ będzie dążyła do przypodobania

18 Zob. art. 118 Konstytucji Rzeczypospolitej Polskiej z dnia 2 kwietnia 1997 r. (Dz.U. z 1997 r. Nr 78, poz. 483 ze zm.).

19 O propozycji Stanisława Gebethnera odrzuconej przez Komisję Konstytucyjną zob. szerzej w pracy R. Chruściak, Sejm i Senat w Konstytucji RP z 1997 r. Powstawanie przepisów, Warszawa 2002, s. 177.

20 Zob. szerzej M. Mistygacz, Rząd w procesie..., op. cit., s. 117-118.

21 Zdestabilizowany parlament rozumiany przeze mnie jest jako izba, w której rozpadła się koalicja rządowa lub partia, która posiadała większość utraciła ją z różnych względów. Postępowanie polityków w takim parlamencie bardzo często nacechowane jest poszukiwaniem nowego ośrodka politycznego, dzięki któremu będzie możliwe 
się alternatywnemu ośrodkowi politycznemu, realizując swoje partykularne interesy. Do tej pory inicjatywy ustawodawcze głowy państwa nie stanowiły jakiejś istotnej konkurencji dla rządu, co w pewnym sensie realizowało pożądany przez ustrojodawców postulat, aby prezydent powściągliwie korzystał z prawa inicjatywy ustawodawczej. Potwierdzają to statystyki, z których wynika, że na tle działalności Rady Ministrów aktywność głowy państwa była w zasadzie symboliczna. Zestawienie liczbowe znajduje się w tabeli 1.

Tabela 1. Liczba zgłoszonych projektów ustaw w poszczególnych kadencjach

\begin{tabular}{|c|c|c|c|}
\hline \multirow{2}{*}{ Kadencje Sejmu } & \multicolumn{3}{|c|}{ Liczba zgłoszonych projektów ustaw (inicjatywy ustawodawcze) } \\
\cline { 2 - 4 } & Rada Ministrów & Prezydent & $\begin{array}{c}\text { \% udzial projektów rzą- } \\
\text { dowych wśród projektów } \\
\text { egzekutywy }\end{array}$ \\
\hline III (lata 1997-2001) & 553 & 16 & 97,2 \\
\hline IV (lata 2001-2005) & 808 & 21 & 97,5 \\
\hline V (lata 2005-2007) & 377 & 23 & 94,3 \\
\hline VI (lata 2007-2011) & 632 & 24 & 96,3 \\
\hline Średnia & $\mathbf{5 9 3}$ & $\mathbf{2 1}$ & $\mathbf{9 6 , 3}$ \\
\hline
\end{tabular}

Źródło: opracowanie własne na podstawie M. Mistygacz, Rola rządu w procesie ustawodawczym w Polsce, Warszawa 2012, s. 285.

Żaden z aktów obowiązującego w Polsce prawa co do zasady nie różnicuje zakresu przedmiotowego inicjatywy ustawodawczej przynależącego uprawnionym podmiotom. Wyjątek od tej zasady stanowi przyznanie Radzie Ministrów w Konstytucji expressis verbis wyłącznego prawa do inicjowania procesu ustawodawczego w zakresie ustawy budżetowej, ustawy o prowizorium budżetowym, zmiany ustawy budżetowej, ustawy o zaciąganiu długu publicznego oraz ustawy o udzielaniu gwarancji finansowych (art. 221 Konstytucji RP). Wyróżnić można jeszcze dwie dodatkowe ścieżki prowadzące do wyłączności inicjatywy ustawodawczej dla rządu. Są nimi projekty ustaw w przedmiocie relacji państwo-kościoły i związki wyznaniowe (tzw. ustawy wyznaniowe) oraz ustawy wyrażające zgodę na ratyfikację umów międzynarodowych ${ }^{22}$. Poza przyznanymi wyłącznymi kompetencjami zgłaszania projektów ustaw Rada Ministrów posiada również jedno ograniczenie w zakresie zgłaszania inicjatyw. Tym wyłączeniem jest niewyposażenie rządu w prawo wniesienia projektu ustawy o zmianie Konstytucji, choć należy podkreślić, że jest to realizacja tzw. funkcji ustrojowej, która posiada dość specyficzne cechy i jako taka rzadko przynależy do obszaru polityki rządowej.

ponowne uzyskanie mandatu parlamentarnego. Często ośrodek prezydencki może być traktowany jako alternatywa polityczna, tak w sposób bezpośredni, jak i pośredni jako inicjator nowego projektu politycznego. 
Rada Ministrów nie posiada także formalnych możliwości oddziaływania na porządek obrad Sejmu, nie może w związku z tym narzucić pierwszeństwa wskazanemu projektowi ustawy $\mathrm{w}$ debacie lub też wystąpić $\mathrm{z}$ wnioskiem o włączenie pewnej określonej sprawy do porządku obrad izby na zasadzie priorytetowej przy spełnieniu określonych warunków ${ }^{23}$. Jedynym narzędziem staje się w tym momencie wpływanie pozainstytucjonalne o charakterze pośrednim sprowadzające się do tego, że po pierwsze Marszałek Sejmu - najczęściej rekrutowany spośród polityków sprawujących władzę - może modyfikować znacząco organizację prac legislacyjnych w izbie niższej, a po drugie posiadane zaplecze polityczne jest w stanie przeforsować decyzje rządowe albo zablokować inne niepożądane projekty. Takie uwarunkowania w kontekście posiadania lub też nie przez dany gabinet rządowy zaplecza większościowego w parlamencie są, jak widać, kluczowe z perspektywy skuteczności oddziaływania na proces legislacyjny. Problem ten uwypuklony jest również w sytuacji wnoszenia gotowego projektu ustawy przez Radę Ministrów, które obwarowane jest szczególnymi wymogami formalnymi, np. koniecznością przeprowadzenia konsultacji, a następnie ujęcia ich wyników w uzasadnieniu projektu wraz $\mathrm{z}$ informacją o przedstawionych wariantach i opiniach, co praktycznie bardzo często przedłuża fazę opracowania projektu w strukturach rządowych. W świetle art. 34 ust. 3 Regulaminu Sejmu ${ }^{24}$ wniosek ten nie dotyczy sejmowych inicjatorów postępowania ustawodawczego, w postaci grupy posłów, bądź komisji sejmowej, co wykonywanie inicjatywy polskiej czyni łatwiejszym niż rządowej, inspirując tym samym strategię ,posługiwania się" posłami wspierającymi rząd, gdy chodzi o sygnowanie konkretnych projektów przygotowywanych przez rządowe służby legislacyjne. Zjawisko zastępowania Rady Ministrów inicjatywą poselską po to tylko, aby uniknąć konieczności wstępnego konsultowania projektu, jest zjawiskiem negatywnie świadczącym o poziomie racjonalności procedury ustawodawczej, a także zamazującym faktyczny obraz procesu legislacyjnego, który dla opinii publicznej staje się nieczytelny, gdyż w wymiarze polityczno-programowym nie wyjaśnia tak naprawdę rzeczywistych działań rządu i popierających go w Sejmie polityków ${ }^{25}$.

Analizując konkurencyjność projektów rządowych z projektami pochodzącymi od innych podmiotów parlamentarnych można zauważyć rosnącą w Polsce aktywność inicjatywną parlamentarzystów, co niestety przy założeniu przyznania Radzie Ministrów priorytetowej roli w zakresie funkcji rządzenia zaburza mechanizm systemowy, gdyż spora część propozycji poselskich de facto odnosi się do spraw bezpośrednio związanych z bieżącym kształtowaniem polityki wewnętrznej i zewnętrznej państwa. Tymczasem proporcje powinny być tu odwrócone i projekty parlamentarne winny jedynie uzupełniać inicjatywną działalność rządu, najczęściej będąc emanacją

\footnotetext{
23 Rada Ministrów w Polsce może co prawda wnioskować o nadanie trybu pilności pewnym projektom, ale jest w tym względzie nieograniczona przedmiotowo.

24 Uchwała Sejmu Rzeczypospolitej Polskiej z dnia 30 lipca 1992 r. Regulamin Sejmu Rzeczypospolitej Polskiej http://www.sejm.gov.pl/prawo/regulamin/kon7.htm (data dostępu: 10.05.2015 r.). 
projektów opozycji parlamentarnej, która w demokracji również ma do odegrania istotną rolę, $\mathrm{z}$ jednej strony recenzenta poczynań rządu, a z drugiej pomysłodawcy alternatywnych rozwiązań w zakresie rządzenia.

W trakcie prac nad złożonym już projektem ${ }^{26}$ Rada Ministrów ma możliwość oddziaływania na proces legislacyjny poprzez mechanizm wnoszenia poprawek do projektu ustawy w toku rozpatrywania go przez Sejm (art. 119 ust. 2 Konstytucji RP). Nie jest to jednak nic szczególnego, gdyż podobne uprawnienia posiadają inne podmioty zaangażowane $\mathrm{w}$ proces ustawodawczy i to zarówno jeśli chodzi o moment wniesienia, jak i zakres treściowy zmian. $\mathrm{O}$ wiele istotniejsze z punktu widzenia skuteczności promowania własnych projektów przez Radę Ministrów jest ingerowanie posłów w treść uchwalanej ustawy w poszczególnych fazach postępowania, a zwłaszcza $\mathrm{w}$ trakcie pierwszego i drugiego czytania sejmowego ${ }^{27}$. W tej sytuacji zgłaszane poprawki posłów do projektów rządowych mogą stać się z jednej strony prawnym instrumentem dialogu między opozycją a rządem lub też narzędziem parlamentarnej obstrukcji, a z drugiej skutecznym środkiem wspierania programu legislacyjnego przez tych parlamentarzystów, którzy stanowią zaplecze polityczne Rady Ministrów.

Kolejnym uprawnieniem oddziaływania rządu na proces ustawodawczy, swego rodzaju „zaworem bezpieczeństwa”, jest prawo wycofania projektu ustawy do czasu zakończenia drugiego czytania (art. 119 ust. 4 Konstytucji RP). To negatywne narzędzie, znajdujące się w dyspozycji wnioskodawcy, ma na celu zapewnienie możliwości wycofania projektu, który w wyniku dotychczasowego procedowania uległ tak daleko idącym przekształceniom, iż stał się dla jego inicjatora całkowicie lub częściowo nie do zaakceptowania. Wycofanie projektu przez Radę Ministrów może być spowodowane krytycznym stanowiskiem posłów wobec przedmiotowej zawartości projektu lub też diametralną zmianą stanowiska wnioskodawcy do złożonego przez niego projektu. Prawo wycofania przez wnioskodawcę projektu ustawy ma zastosowanie do Rady Ministrów zwłaszcza wówczas, kiedy zmienia się konfiguracja większości parlamentarnej legitymizującej rząd, co jednak nie chroni go w jakiś szczególny sposób ${ }^{28}$.

W literaturze przedmiotu powszechny jest również pogląd, że w sejmowym postępowaniu ustawodawczym pozycję przetargową rządu można wzmocnić poprzez formułę, według której akceptacja rządowego projektu ustawy oznacza jednoczesne postawienie kwestii zaufania dla gabinetu. Taki nacisk wywierany na legislatywę przez egzekutywę mógłby być korzystny, zwłaszcza jeśli uwzględni się dość skomplikowaną sytuację gabinetów mniejszościowych. Dotychczasowa praktyka m.in. rządów Jerzego Buzka, Leszka Millera, Marka Belki, czy Jarosława Kaczyńskiego pokazuje, z jednej, strony ogromne trudności w uchwalaniu koniecznych ustaw o du- 
żym rezonansie społecznym, a z drugiej problem przy próbie konstruowania alternatywnego gabinetu w miejsce słabego i nieskutecznego rządu ${ }^{29}$.

Analizując pozycję rządu i jego skuteczność legislacyjną nie można zapominać o relacjach z prezydentem wyposażonym w dość samodzielne i nieskrępowanie prawo do odmowy podpisania ustawy. Wydaje się, że ta możliwość stosowania tzw. weta ustawodawczego w formule prezydenckiej prerogatywy jest traktowana jako główny instrument arbitrażu politycznego głowy państwa daleko wykraczający poza ramy klasycznego modelu parlamentarno-gabinetowego ${ }^{30}$. Krytyczna ocena dzisiejszego kształtu prezydenckiego weta ustawodawczego, jako głównie instrumentu korygowania polityki prowadzonej przez rząd, powoduje pojawianie się propozycji mających na celu modyfikację rozwiązań normatywnych w tym kierunku, aby stało się ono środkiem służącym zapewnieniu równowagi między legislatywą i egzekutywą ${ }^{31}$.

Kluczowym wyznacznikiem faktycznej pozycji Rady Ministrów jako podmiotu uczestniczącego w legislacji jest ilościowy udział rządowych projektów ustaw na tle projektów ustaw w ogóle. W tabeli 2. przedstawiono zestawienie statystyczne tych projektów w świetle obowiązujących po 1997 roku rozwiązań konstytucyjnych. Dla całego okresu III RP widoczny jest wzrost i znaczenie projektów rządowych.

Tabela 2. Rządowe projekty ustaw na tle projektów innych podmiotów

\begin{tabular}{|c|c|c|c|c|c|c|c|}
\hline \multirow{2}{*}{$\begin{array}{l}\text { Kadencje } \\
\text { Sejmu }\end{array}$} & \multicolumn{7}{|c|}{ Liczba zgłoszonych projektów ustaw (inicjatywy ustawodawcze) } \\
\hline & $\begin{array}{c}\text { Rada } \\
\text { Ministrów }\end{array}$ & Posłowie & $\begin{array}{l}\text { Komisje } \\
\text { sejmowe }\end{array}$ & Senat & Prezydent & Obywatele & Razem \\
\hline $\begin{array}{c}\text { III (lata } \\
1997-2001)\end{array}$ & $553(48 \%)$ & $469(41 \%)$ & $82(7 \%)$ & $27(2 \%)$ & $16(1 \%)$ & $5(1 \%)$ & 1152 \\
\hline $\begin{array}{c}\text { IV (lata } \\
2001-2005)\end{array}$ & $808(64 \%)$ & $358(28 \%)$ & $40(3 \%)$ & $25(2 \%)$ & $21(2 \%)$ & $13(1 \%)$ & 1265 \\
\hline $\begin{array}{c}\text { V (lata } \\
2005-2007)\end{array}$ & $377(53 \%)$ & $273(39 \%)$ & $11(2 \%)$ & $16(2 \%)$ & $23(3 \%)$ & $8(1 \%)$ & 708 \\
\hline $\begin{array}{c}\text { VI (lata } \\
2007-2011)\end{array}$ & $674(45 \%)$ & $493(33 \%)$ & $183(12 \%)$ & $114(7 \%)$ & 28 (2\%) & 19 (1\%) & 1511 \\
\hline $\begin{array}{c}\text { VII (lata } \\
2011-2015)\end{array}$ & 404 (35\%) & $566(50 \%)$ & 34 (3\%) & 94 (8\%) & $21(2 \%)$ & 24 (2\%) & 1143 \\
\hline Średnia & 2816 (49\%) & 2159 (37\%) & $350(6 \%)$ & 276 (5\%) & $\begin{array}{l}109 \\
(2 \%)\end{array}$ & $\begin{array}{c}69 \\
(1 \%)\end{array}$ & $\begin{array}{c}\mathbf{5 7 7 9} \\
(100 \%)\end{array}$ \\
\hline
\end{tabular}

Źródło: opracowanie własne na podstawie M. Mistygacz, Rząd w procesie ustawodawczym w Polsce, Warszawa 2012, s. 197-208; A. Dudzińska, System zamknięty. Socjologiczna analiza procesu legislacyjnego, Warszawa 2015, s. 71.

29 M. Mistygacz, Rząd w procesie..., op. cit., s. 360, S. Patyra, Wpływ Rady Ministrów na proces..., op. cit., s. $134-135$.

30 R. Mojak, Instytucja Prezydenta RP w okresie przekształceń ustrojowych, Lublin 1995, s. 217.

31 Koncepcja prezydenta jako „rzecznika egzekutywy” czyni zasadnym występujący w literaturze przedmiotu postulat powiązania kompetencji prezydenta - na wzór francuski - z kontrasygnatą premiera lub też zgodnie z modelem niemieckim objęcie kontrasygnatą premiera aktu promulgacji ustawy. Zob. szerzej S. Patyra, Wpływ Rady Ministrów na proces..., op. cit., s. 136-138. 
Zestawienie z kolei tabeli 3. i tabeli 4. pozwala zauważyć zależność pomiędzy skutecznością legislacyjną ${ }^{32}$ projektów rządowych w ogóle a skutecznością projektów rządowych zgłaszanych w sytuacji braku większości parlamentarnej (tzw. rządów mniejszościowych).

Tabela 3. Gabinety mniejszościowe w Polsce w latach 1991-2015

\begin{tabular}{|l|c|c|c|c|c|}
\hline \multicolumn{1}{|c|}{ Premier } & $\begin{array}{c}\text { Zaplecze } \\
\text { partyjne } \\
\text { parlamencie }\end{array}$ & $\begin{array}{c}\text { Okres } \\
\text { funkcjonowania }\end{array}$ & $\begin{array}{c}\text { Trwałość } \\
\text { w miesią- } \\
\text { cach }\end{array}$ & Status & $\begin{array}{c}\text { Podział Le- } \\
\text { wica-Pra- } \\
\text { wica }\end{array}$ \\
\hline $\begin{array}{l}\text { Jan Olszewski } \\
\text { (PC) }\end{array}$ & $\begin{array}{c}\text { PC, ZChN, PL, } \\
\text { NSZZ „S” }\end{array}$ & $\begin{array}{c}05.12 .1991 \\
-05.06 .1992\end{array}$ & 6 & $\begin{array}{c}\text { koalicja } \\
\text { mniejszościowa }\end{array}$ & Prawicowy \\
\hline $\begin{array}{l}\text { Hanna Suchocka } \\
\text { (UD) }\end{array}$ & $\begin{array}{c}\text { UD, ZChN, KLD, } \\
\text { PL, PChD, SLCh, } \\
\text { PPG }\end{array}$ & $\begin{array}{c}05.06 .1992 \\
-25.05 .1993\end{array}$ & 10,5 & $\begin{array}{c}\text { koalicja } \\
\text { mniejszościowa }\end{array}$ & Prawicowy \\
\hline $\begin{array}{l}\text { Jerzy Buzek } \\
\text { (AWS) }\end{array}$ & AWS & $\begin{array}{c}07.06 .2000 \\
-19.10 .2001\end{array}$ & 16,5 & $\begin{array}{c}\text { jednopartyjny } \\
\text { mniejszościowy }\end{array}$ & Prawicowy \\
\hline $\begin{array}{l}\text { Leszek Miller } \\
\text { (SLD) }\end{array}$ & SLD & $\begin{array}{c}04.03 .2003 \\
-04.05 .2004\end{array}$ & 14 & $\begin{array}{c}\text { jednopartyjny } \\
\text { mniejszościowy }\end{array}$ & Lewicowy \\
\hline $\begin{array}{l}\text { Marek Belka } \\
\text { (bezp.) }\end{array}$ & SLD & $\begin{array}{c}05.05 .2004 \\
-31.10 .2005\end{array}$ & 18 & $\begin{array}{c}\text { jednopartyjny } \\
\text { mniejszościowy }\end{array}$ & Lewicowy \\
\hline $\begin{array}{l}\text { Kazimierz Marcin- } \\
\text { kiewicz (PiS) }\end{array}$ & PiS & $\begin{array}{c}31.10 .2005 \\
-26.04 .2006\end{array}$ & 5,5 & $\begin{array}{c}\text { jednopartyjny } \\
\text { mniejszościowy }\end{array}$ & Prawicowy \\
\hline $\begin{array}{l}\text { Jarosław Kaczyń- } \\
\text { ski (PiS) }\end{array}$ & PiS, LPR & $\begin{array}{c}21.09 .2006 \\
-15.10 .2006\end{array}$ & 1 & $\begin{array}{c}\text { koalicja } \\
\text { mniejszościowa }\end{array}$ & Prawicowy \\
\hline $\begin{array}{l}\text { Jarosław Kaczyń- } \\
\text { ski (PiS) }\end{array}$ & PiS & $\begin{array}{c}11.08 .2007 \\
-16.11 .2007\end{array}$ & 4,5 & $\begin{array}{c}\text { jednopartyjny } \\
\text { mniejszościowy }\end{array}$ & Prawicowy \\
\hline
\end{tabular}

Źródto: opracowanie własne na podstawie A. Antoszewski, System polityczny RP, Warszawa 2012, s. 205; Rzady koalicyjne w III RP, M. Chmaj (red.), Olsztyn 2006, passim; M. Migalski, W. Wojtasik, M. Mazur, Polski system partyjny, Warszawa 2006, passim.

Tabela 4. Skuteczność legislacyjna rządu w świetle skuteczności innych podmiotów

\begin{tabular}{|l|c|c|c|c|c|c|c|}
\hline \multirow{2}{*}{ Kadencje Sejmu } & \multicolumn{7}{|c|}{ Skuteczność legislacyjna w \% } \\
\cline { 2 - 8 } & $\begin{array}{c}\text { Rada } \\
\text { Ministrów }\end{array}$ & Posłowie & $\begin{array}{c}\text { Komisje } \\
\text { sejmowe }\end{array}$ & Senat & Prezydent & Obywatele & Średnia \\
\hline $\begin{array}{l}\text { III (lata } \\
\text { 1997-2001) }\end{array}$ & 81 & 41 & 78 & 41 & 31 & 40 & $\mathbf{5 2}$ \\
\hline $\begin{array}{l}\text { IV (lata } \\
\text { 2001-2005) }\end{array}$ & 91 & 51 & 82 & 64 & 71 & 38 & $\mathbf{6 6 , 1 7}$ \\
\hline V (lata 2005-2007) & 77 & 44 & 27 & 19 & 74 & 12 & $\mathbf{4 2 , 1 7}$ \\
\hline $\begin{array}{l}\text { VI (lata } \\
\text { 2007-2011) }\end{array}$ & 96 & 41 & 69 & 78 & 54 & 11 & $\mathbf{5 8 , 1 7}$ \\
\hline
\end{tabular}

32 Przyjmuje się, że skuteczność legislacyjna może być rozpatrywana jako relacja pomiędzy uchwalonymi z inicjatywy rządu ustawami a przedłożonymi przez wnioskodawcę (rząd) projektami. 
Skuteczność legislacyjna gabinetów mniejszościowych (wybrane aspekty)

\begin{tabular}{|l|c|c|c|c|c|c|c|}
\hline VII (2011-2015) & 89 & 31 & 65 & 61 & 48 & 8 & $\mathbf{5 0 , 3 3}$ \\
\hline Średnia & $\mathbf{8 6 , 8}$ & $\mathbf{4 1 , 6}$ & $\mathbf{6 4 , 2}$ & $\mathbf{5 2 , 6}$ & $\mathbf{5 5 , 6}$ & $\mathbf{2 1 , 8}$ & - \\
\hline
\end{tabular}

Źródło: opracowanie własne na podstawie M. Mistygacz, Rząd w procesie ustawodawczym w Polsce, Warszawa 2012, s. 292-294; A. Dudzińska, System zamknięty. Socjologiczna analiza procesu legislacyjnego, Warszawa 2015, s. 71.

W świetle tych danych widać korelację polegającą na tym, że w kadencjach parlamentu III, IV i V, w których funkcjonowały rządy mniejszościowe, skuteczność legislacji rządu była mniejsza niż w kadencji VI, w której funkcjonował koalicyjny rząd większościowy. Co prawda, w kadencji IV odsetek powodzenia w uchwaleniu projektów rządowych był na przyzwoitym wysokim poziomie, pomimo istnienia rządu bez poparcia większości, jednakże ten stan był uwarunkowany specyficzną sytuacją polityczną, wynikającą z procesu akcesji Polski do Unii Europejskiej. W tym okresie intensyfikowano prace legislacyjne mające na celu dostosowanie prawa polskiego do unijnego i prym w zakresie tworzenia propozycji i modyfikacji rozwiązań normatywnych wiódł rząd jako najlepiej poinformowany i przygotowany merytorycznie uczestnik procesu.

Zauważyć również należy, że rządy mniejszościowe nie były w stanie przeforsować żadnych istotnych projektów ustaw i potwierdzała się teza o administracyjnym charakterze tego typu gabinetów bez strategicznej wizji rządzenia. W okresach, kiedy funkcjonował rząd mniejszościowy, nie można odnotować żadnych ważnych ustaw, czy projektów, które w zasadniczy sposób przemodelowałyby dotychczasowe rozwiązania, a liczba uchwalanych z inicjatywy gabinetów projektów malała szczególnie w tym czasie, obniżając tym samym średnią wyliczaną dla całej kadencji parlamentu. Po części przyczyną tego stanu rzeczy jest również niepodejmowanie przez rząd mniejszościowy tego typu inicjatyw, które często w założeniach są kontrowersyjne i dla ich powodzenia wymagane jest poparcie większości w izbie niższej. Nie ma tu znaczenia rozwiązanie normatywne, które jest takie samo jak w przypadku rządu dysponującego zapleczem większościowym czy tylko mniejszościowym.

Ilustracją tego typu zjawisk są porażki legislacyjne na przykład rządu Marka Belki. W niektórych przypadkach, zwykle związanych z wprowadzeniem rozwiązań społecznie kosztownych, brak skuteczności rządowych inicjatyw był następstwem ograniczonego zdyscyplinowania posłów z klubów parlamentarnych formalnie ten gabinet popierających. Na przykład w czasie głosowań w Sejmie w dniu 19 listopada 2004 roku sprawozdanie komisji, w którym wnioskowano o odrzucenie rządowego projektu zmian dotyczących emerytur i rent zostało przyjęte przy 419 głosujących, 209 głosami za przy 207 przeciw, co było możliwe m.in. dlatego, że aż 12 posłów z SLD nie głosowało, a 1 się wstrzymał. Wśród innych prestiżowych głosowań, w których rząd poniósł klęskę wymienić można głosownia m.in.: nad wnioskiem o odrzucenie informacji rządu o realizacji umowy offsetowej między Skarbem Pań- 
stwa a firmą Lockheed Martin z USA; nad Narodowym Planem Rozwoju na lata 2007-2013; nad założeniami i realizacją procesu konsolidacji przemysłu naftowego w Polsce; nad ustawą o podatku ekologicznym ${ }^{33}$. Podobne tendencje obserwowano w czasie rządów mniejszościowych Jerzego Buzka, Leszka Millera, czy Kazimierza Marcinkiewicza, choć w poszczególnych przypadkach inne było zarządzanie zapleczem politycznym i inna czasami jego konsolidacja.

Podsumowując można na podstawie polskich doświadczeń potwierdzić założoną we wstępie hipotezę o tym, że funkcjonowanie gabinetów mniejszościowych nie sprzyja skuteczności legislacyjnej rządów bez stabilnego oparcia w parlamencie. Wpływ na to ma nie tylko brak większości do przegłosowywania ustaw, ale także inne czynniki wewnętrzne, które ostatecznie mogą doprowadzić tak do upadku rządu, jak i w ogóle skrócenia kadencji, co powoduje zastosowanie zasady dyskontynuacji prac parlamentarnych. Odrębną kwestią wymagającą dalszych badań jest faktyczne ustalenie autorstwa projektów, co w sytuacji skomplikowanej materii ustawodawczej oraz w kontekście działań politycznych nie jest przedsięwzięciem łatwym i ostatecznie możliwym do rozgraniczenia.

\section{BIBLIOGRAFIA}

Chruściak Ryszard. 2002. Sejm i Senat w Konstytucji RP z 1997 r. Powstawanie przepisów. Warszawa: Wydawnictwo Sejmowe.

Dudzińska Agnieszka. 2015. System zamknięty. Socjologiczna analiza procesu legislacyjnego. Warszawa: Wydawnictwo Naukowe SCHOLAR.

Jaskiernia Jerzy. 1999. Zasada demokratycznego państwa prawnego w sejmowym postępowaniu ustawodawczym. Warszawa: Wydawnictwo Sejmowe.

Konstytucji Rzeczypospolitej Polskiej z dnia 2 kwietnia 1997 r. (Dz.U. Nr 78, poz 483 ze zm.).

Małajny Ryszard. 2009. „Idea rozdziału władzy państwowej i jej interpretacje”. Przegląd Sejmowy. (1): 81-106.

Małajny Ryszard. 2001. Trzy teorie podzielonej władzy. Warszawa: Wydawnictwo Sejmowe.

Mistygacz Michał. 2012. Rola rządu w procesie ustawodawczym (w systemie parlamentarnym). W Parlamentarny system rządów. Teoria i praktyka, 282-295. Warszawa: Dom Wydawniczy Elipsa.

Mistygacz Michał. 2012. Rząd w procesie ustawodawczym w Polsce. Warszawa: Dom Wydawniczy Elipsa.

Mojak Ryszard. 1995. Instytucja Prezydenta RP w okresie przekształceń ustrojowych. Lublin: Wydawnictwo Uniwersytetu Marii Curie-Skłodowskiej.

Mojak Ryszard. 2007. Parlament a rząd w ustroju Trzeciej Rzeczypospolitej Polskiej. Lublin: Wydawnictwo Uniwersytetu Marii Curie-Skłodowskiej.

33 G. Rydlewski, Rząd Marka Belki (2 V 2004 - 31 X 2005), (w:) M. Chmaj (red.), Rządy kolacyjne w III RP, Olsztyn 2006, s. $270-271$. 
Mróz Remigiusz. 2013. „Rząd mniejszościowy”. Przegląd Sejmowy. (1): 35-46.

Patyra Sławomir. 2011. Wpływ Rady Ministrów na proces ustawodawczy w kontekście racjonalizacji systemu rządów. W Wybrane aspekty parlamentaryzmu zracjonalizowanego, 117-139. Lublin: Wyższa Szkoła Ekonomii i Innowacji w Lublinie.

Rot Henryk. 1994. Wartości demokratyczne i racjonalistyczne studium ustanawiania aktów prawotwórczych. W Demokratyczne państwo prawne (aksjologia, struktura, funkcje), 128-142. Wrocław: Wydawnictwo Uniwersytetu Wrocławskiego.

Rydlewski Grzegorz. 2006. Rząd Marka Belki (2 V 2004 - 31 X 2005). W Rządy kolacyjne w III RP, 257-275. Olsztyn: Wydawnictwo Uniwersytetu Warmińsko-Mazurskiego.

Rządy mniejszościowe w wybranych państwach świata. Studium prawno-politologiczne. 2014. (red.) Robert Radek. Katowice: Instytut Nauk Politycznych i Dziennikarstwa.

Strøm Kaare. 1990. Minority Government and Majority Rule. Cambridge: University Press.

Szymanek Jarosław. 2007. „Racjonalizacja parlamentarnego systemu rządów”. Przegląd Sejmowy (1): 35-64.

Uchwała Sejmu Rzeczypospolitej Polskiej z dnia 30 lipca 1992 r. Regulamin Sejmu Rzeczypospolitej Polskiej http://www.sejm.gov.pl/prawo/regulamin/kon7.htm

Zakrzewski Piotr. 2009. Rząd mniejszościowy - zagadnienia definicyjne i przegląd stanowisk teoretycznych, 92-102. W Wielowymiarowość systemów politycznych. Teoretyczne założenia i praktyczne uwarunkowania. Warszawa Dom Wydawniczy Elipsa.

Zakrzewski Piotr. 2015. Rządzy mniejszościowe w III Rzeczypospolitej. Warszawa: Oficyna Wydawnicza ASPRA-JR. 


\section{EFFECTIVENESS OF MINORITY GOVERNMENT LEGISLATION (SELECTED ASPECTS)}

Contemporary states are facing major dilemmas of governance. One of them is the effectiveness of governance, which can be judged by the effectiveness of the legislation. Today, governments are making efforts to develop major policy guidelines and ensuring their implementation using all available instruments. The main aim of this article is to analyze certain aspects of the government's involvement in the legislative process and the effectiveness of minority government legislation. The author analyzes the impact of governmental regime on the position of the cabinet in Poland, explains the mechanisms of normative and political influence on the formation of the law and hypothesizes that the functioning of government without a clear majority in parliament makes it difficult, or even impossible to adopt laws bearing great social and political impact on the state. It is noticed that the governmental political base is really crucial when we think about the effectiveness of legislation at all. The assumptions are indirectly confirmed by data on the effectiveness of the legislation of governments in selected years.

Keywords: minority government, legislation, majority

Słowa kluczowe: rząd mniejszościowy, legislacja, większość 